\title{
James Sloan: Renegade or True Republican?
}

\author{
Bruce Bendler ${ }^{1}$
}

\begin{abstract}
This paper examines the political career of James Sloan of Gloucester County, New Jersey. Sloan was instrumental in organizing the Democratic Republican party in Gloucester County, and he represented New Jersey in the United States House of Representatives from 1803 to 1809. Sloan was born into a Quaker family, but he supported the Whig cause in the American Revolution and faced disciplinary action from his Quaker meeting for doing so. Later, he would gravitate toward Methodism, but he never seemed comfortable in any religious organization. Historian Carl Prince called Sloan an "anomaly" in New Jersey politics. Sloan's career certainly did manifest anomalous behavior. He criticized his party after it took control of the state legislature in 1801, viewing its implementation of republican principles as insufficiently zealous. As a member of Congress, he broke with the Jefferson administration over the Embargo. After leaving Congress, he coalesced with New Jersey Federalists in opposition to the War of 1812, helping to elect a "peace ticket" in that year. This paper examines Sloan's role in state and national politics in the very early nineteenth century. Specifically, it points out some of the tensions within the Democratic Republican party, especially among those who were displeased with the domination of the "Virginia Dynasty." Sloan led efforts to challenge this domination and to offer alternatives to the New Jersey electorate.
\end{abstract}

On September 21, 1808, New Jersey's Democratic Republicans met in convention to nominate a slate of candidates to the United States Congress. The convention denied nomination to a threeterm incumbent, James Sloan of Gloucester County. In a letter to the public, the delegates to the convention praised Sloan's replacement Jacob Hufty and another newcomer for the "soundness of their political principles." "Unstated but implicit was that Sloan's principles were not as sound. Indeed, only a few months earlier, James Sloan had argued against the embargo imposed by the Jefferson administration and had opposed James Madison, the party's nominee to succeed Thomas Jefferson. Sloan had in fact become disillusioned with Jefferson's foreign policy and undoubtedly feared that the election of Madison would mean its continuation. By challenging party orthodoxy, Sloan had acquired a reputation as a renegade in his own party. In so doing, however, he offered an alternative variety of republicanism, one that found greater acceptance as the nation moved toward war in 1812. But throughout his controversial career, Sloan saw himself as a true republican, and many of his fellow partisans came to see merit in his opposition to the "Virginia Dynasty."

James Sloan was born on October 10, 1748, in Newton Township, then part of Gloucester County, New Jersey. He was named for his father, who had moved to Newton Township from Bucks County, Pennsylvania in 1746. On September 6, 1746, the elder Sloan, a Quaker, applied for and received a certificate to transfer from the Richland, Pennsylvania Monthly Meeting to the Haddonfield, New Jersey Monthly Meeting. ${ }^{3}$ When the younger James Sloan was about four years old, his father purchased one hundred acres of land in Newton Township. ${ }^{4}$ Sloan Sr. had married into an old Gloucester County family on June 14, 1734. Mary Cooper Sloan was a descendent of one of Newton's pioneer families with roots in the township dating to the 1680s.

\footnotetext{
${ }^{1}$ Bruce Bendler teaches history at the University of Delaware and at Wesley College.

${ }^{2}$ Palladium of Liberty, October 10, 1808.

${ }^{3}$ Minutes of Richland Monthly Meeting, 1743-1764, 580, Friends Historical Library, Swarthmore College (hereafter cited as FHL).

${ }^{4}$ Gloucester County Deed, C-289.
} 


\section{Bendler}

The Sloans thus joined a Quaker community, established even before William Penn's colonization of Pennsylvania in 1682, which formed the backbone of economic and social life in West Jersey.

James Sloan became a major political figure in Gloucester County and in New Jersey, but his political career was unique in many ways. Historian Carl Prince called him "an anomaly among Republicans," and a "Quaker Jeffersonian politician." Indeed Prince portrayed Sloan as "irascible," and frequently at odds politically with his fellow Jeffersonian Republicans. Sloan's peers often viewed him in the same light. Even before entering politics, he tended to think for himself, never fully conforming to the teachings of his family's Quaker faith.

Once involved in politics, he often found himself in conflict with his fellow Jeffersonians at the local, state, and national levels. His political career sheds light on the fissures that developed in the Democratic Republican party after it acquired power in New Jersey in 1801. Sloan's pugnacious approach to politics probably widened some of those fissures, but differences in political philosophy between Sloan and his peers no doubt contributed to their development as well. Sloan first emerged as a Democratic Republican leader in Gloucester County in 1800, when he championed Jefferson's concept of American democracy and excoriated the Federalist administration of John Adams. But between 1801 and 1805, a battle for control of the party organization in Gloucester County developed in part because Sloan did not believe his opponent, Joseph Cooper, acted with sufficient vigor to implement party principles. He therefore challenged his fellow partisans, doing so with blunt rhetoric.

Sloan won election to the first of three terms in the United States House of Representatives in $1803 .{ }^{6}$ By the end of his third term in Washington, Sloan broke with the national party over issues such as the Embargo and slavery. In 1812, other disgruntled Democratic Republicans in New Jersey joined Sloan and united with their former political enemies, the Federalists, to form a "Friends of Peace" ticket in opposition to the declaration of war on Great Britain. For Sloan, the war was only one of several points of nonconformity with his party. Indeed, throughout his political career, Sloan combined ambition and principle in a way that led him to eschew total conformity to the party he had helped to organize in Gloucester County.

\section{Sloan's Early Career in Gloucester County}

Early in his career, James Sloan, Jr. refused to conform to the "peace testimony" of the Quaker community and supported the revolutionary government of New Jersey. On August 9, 1779, elders of the Haddonfield meeting "spoke with" Sloan, admonishing him for "taking of the Test of Allegiance as prescribed by a law of the present government."7 Two months later, Sloan responded to the elders, stating that he would "continue to support and justify his conduct" and

\footnotetext{
${ }^{5}$ Carl Prince, New Jersey's Jeffersonian Republicans: The Genesis of an Early Party Machine, 1789-1817 (Chapel Hill: University of North Carolina Press, 1967), 52.

${ }^{6}$ Examination of Sloan's career adds personal and ideological dimensions to Prince's examination of the development of "tightly knit" democratic associations after 1800. Sloan's abrasive personality and his harsh criticism of fellow partisans exposed tensions within even such "tightly knit" organizations. Sloan found it difficult to remain loyal to an organization, even one of his own making. See Prince, New Jersey's Jeffersonian Republicans, xiv-xv and 247-253.

${ }^{7}$ Minutes of the Haddonfield Monthly Meeting, 1761-1781, 402, FHL.
} 
would "give no expectation of offering any satisfaction" to the meeting. ${ }^{8}$ On December 13, 1779, the elders concluded that Sloan had manifested "disregard to the unity of the brethren" and denied him the "privilege of setting in our meetings for the transacting of the affairs of the church until he is brought to a sense of his deviation. .."9 Sloan did not recant his support of the Whig cause; instead, he became even more deeply involved in it. By 1780, he had enlisted in the local militia of Newton Township, serving as a private in the company of Captain John Stokes which marched to Morristown to support the Continental Army. ${ }^{10}$ His service in the Whig cause and his ambivalent attitude to Quaker teachings became important issues when he entered the political arena. $^{11}$

On April 25, 1792, Sloan inherited his father's estate of 170 acres on Newton Creek. ${ }^{12}$ On the same date that he received his patrimony, James Sloan completed a transaction that certainly affected his future political career. He agreed to a ninety-nine year lease with Joseph Ellis for a plot of three square rods on the south bank of Newton Creek. He agreed to erect thereon "a building for the convenience of depositing therein sails, oars, and other utensils to be made use of by the said Sloan and his heirs." ${ }^{13}$ The intent of this transaction was to establish a connection between the agricultural hinterland of Gloucester County and the marketplace in Philadelphia. By making this acquisition, Sloan could establish contacts with farmers and merchants who crossed the Delaware River to market and exchange their produce and thus set up a network of acquaintances among people involved in commerce between Philadelphia and the rich agricultural lands of southern New Jersey. He could then exploit such acquaintances and contacts when he entered politics.

James Sloan established other politically beneficial connections. Although he had run afoul of the leadership of the Haddonfield Monthly Meeting some years before, Sloan did support the antislavery stance of the Quaker community. He joined the Gloucester County Society for Promoting the Abolition of Slavery in 1794, serving briefly as its acting chair in $1797 .{ }^{14}$ In 1795 , he served with his brother Joseph as a delegate from New Jersey to a convention of regional abolition societies held in Philadelphia. ${ }^{15}$ Another delegate from Gloucester County, Franklin Davenport, would in time become a political adversary. Sloan served on a committee to report on measures adopted by former conventions regarding petitions and memorials to the United States Congress and to state legislatures. ${ }^{16}$

\footnotetext{
${ }^{8}$ Ibid, 404.

${ }^{9}$ Ibid, 407.

${ }^{10}$ New Jersey Archives, Mss. 10783, New Jersey State Archives, Trenton, New Jersey.

${ }^{11}$ Craig Koedel discusses the Quaker discipline of those members who participated in the Revolution. See Koedel, God's Vine in the Wilderness (Woodbury, New Jersey: Gloucester County Historical Society, 1980), 119-126. For discussion of this matter in a broader context, see Jack D. Marietta, The Reformation of American Quakerism, 1748-1783 (Philadelphia: University of Pennsylvania Press, 1984). Marietta emphasizes how Quakers coupled stricter internal discipline with increasing aversion to worldly pursuits.

${ }^{12}$ Gloucester County Deed, C-224.

${ }^{13}$ Gloucester County Deed, C-292.

${ }^{14}$ Minutes of the Society, on http://www.westjerseyhistory.org/docs/timhack/index.shtml, accessed June 21, 2010.

${ }^{15}$ Minutes of the Proceedings of a Convention of Delegates from the Abolition Societies Established in Different Parts of the United States, Assembled at Philadelphia, January 7, 1795 (Philadelphia: Zachariah Poulson, 1795$), 7$. ${ }^{16}$ Ibid., 10.
} 
Sloan entered Newton Township politics soon after the end of the Revolutionary War. In the 1780s, he held a number of township offices, including that of tax assessor. ${ }^{17}$ In 1786 , he led a successful effort to build a dam and embankments on the Newton Creek, near his own residence. ${ }^{18}$ In 1792 and 1794, he represented Newton Township on the Gloucester County Board of Chosen Freeholders. ${ }^{19}$ Service as a freeholder enabled him to make his name known across the county. In 1797, he won appointment as a justice for Gloucester County. ${ }^{20}$ Political connections now complemented the economic, religious, and social ones he had already established.

Sloan thus positioned himself to take a leading role in Gloucester County politics. Connections with farmers and merchants and involvement in the antislavery movement supported by Gloucester County's substantial Quaker population enabled Sloan to draw on the support of two key constituencies in the county. By 1800, he took his first steps into the Democratic Republican politics of Gloucester County. He did so at a time when that opposition had begun to challenge Federalist political dominance in southern New Jersey. State party leaders observed the increased Democratic Republican activity there. On July 25, 1800, Mahlon Dickerson reported, in a letter to his brother Silas, that a "very favorable change has taken place in Salem, Cumberland, Cape May, and even in Gloucester" counties. ${ }^{21}$ On August 14, 1800, Mahlon again noted, in another letter to Silas, that "republicans in Gloucester, and even in Burlington County, are raising their heads" in heretofore Federalist bastions. ${ }^{22}$

\section{Building a County Party Organization}

James Sloan organized and took charge of the new Democratic Republican organization in Gloucester County in the late summer of 1800. On July 28, 1800, Democratic Republicans met at a public schoolhouse to establish a committee and elected James Sloan to the chair. Apparently, some Federalists attended the meeting and challenged Sloan's election. Sloan responded to this challenge with an address later described as "masterly and well-timed.",23 The Democratic Republicans then adjourned and reconvened in the home of a supporter, Aaron Chew, who lived near Big Timber Creek. Federalists, who claimed that Sloan's purpose was to stifle "full and free discussion of political issues and craft a political statement," held a meeting of their own on August $4 .{ }^{24}$ A series of meetings held by both sides ensued, and by September of 1800, the two parties had established committees and nominated tickets to contest the October elections.

\footnotetext{
${ }^{17}$ Newton Township meeting records, Clement Papers, Historical Society of Pennsylvania, Philadelphia. Gloucester County Rateables, 1773-1822, Newton Township, Gloucester County Historical Society, Woodbury, New Jersey (hereafter: GCHS).

${ }^{18}$ Legislative Papers, Record Group SLE00002, Box 6, Petitions Re: Bridges, Canals, Dams, Ferries, and Roads, 1765-1835, New Jersey Department of Archives and Records Management, Trenton, New Jersey; and Acts of the Eleventh General Assembly of New Jersey (Trenton: Isaac Collins, 1786), 356-363.

${ }^{19}$ Gloucester County Board of Chosen Freeholder's Records, 1701-1797, transcribed by the GCHS, $229,298$.

${ }^{20}$ Ibid., 298.

${ }^{21}$ Mahlon Dickerson to Silas Dickerson, July 25, 1800, Dickerson family papers, Box 3, New Jersey Historical Society, Newark (hereafter: NJHS).

${ }^{22}$ Mahlon Dickerson to Silas Dickerson, August 14, 1800, Dickerson family papers, Box 3, NJHS.

${ }^{23}$ Centinel of Freedom, Newark, New Jersey, August 5, 1800.

24 "At a Meeting of the Inhabitants of Gloucester County Held on the $4^{\text {th }}$ Day of August 1800", broadside, n. p., 1800 .
} 
On September 6, Sloan addressed a meeting of his party's committee, castigating the Federalist Adams administration on two counts. First, he called the Federalists a "deceptive insidious party attached to the tyrannical form of government from which we have so lately been emancipated." Second, he accused the Federalists of establishing an "aloof" executive branch, as "independent of the people as the court of Great Britain." 25 Sloan also raised an issue that, in his mind, was among the most important then under debate in New Jersey. Sloan advocated the simplification of the state's legal code by eliminating use of the British common law by the New Jersey judiciary. According to Sloan, the common law enriched wealthy (mainly Federalist) lawyers and created unnecessary expenses for average citizens. He urged Gloucester County's diverse social and religious community to "rise in a mass" to promote a "perfect system of democracy," as well as a higher level of "morality and virtue." 26 Although the Federalists again elected their ticket in Gloucester County in 1800, the opposition, led by Sloan, had established a strong, competitive organization.

Sloan's firm attachment to Democratic Republican principles became clearer by the late summer of 1801, when the campaign for the elections that fall began to heat up. He addressed the newlyorganized Democratic Association of the County of Gloucester on August 31, 1801. He rehashed his scathing critique of Federalist rule, pointing to the hypocrisy of a party that made "high professions of Christianity" but sought to "undermine and destroy the fine fabric of our liberties." The funding system, the Jay Treaty, the Alien and Sedition Acts, and the effort to raise a standing army, Sloan contended, all provided proof of Federalist attachment and subservience to Great Britain and British political culture, accompanied by contempt for democracy. ${ }^{27}$ Sloan insinuated that New Jersey Federalists had supported efforts to establish an "absolute military despotism" during the crisis of $1798 .^{28}$

Sloan contrasted the perceived despotic rule of the Federalists with the policies of the still-young administration of Thomas Jefferson. In its less than six months in office, the new administration had cut government spending, reduced the number of officeholders, eliminated "pomp and ceremonies" in the conduct of official business, and allowed Thomas Paine to reenter the United States. Under a "meek and amiable" democrat like Jefferson, "numerous democratic societies for the purpose of disseminating knowledge" could and did flourish. ${ }^{29}$

Sloan also raised the issue of the role of organized religion in government and politics. He noted that Federalist pamphlets had attacked Jefferson's deistic beliefs, hoping to encourage more orthodox Christian believers to vote against Jefferson and his party. But Sloan portrayed Federalists as champions of a religious establishment averse to democracy, especially in New England, where the Congregational Church remained established by law in Massachusetts and Connecticut. In contrast, Jefferson firmly supported religious freedom.

Religion and its role in political discourse had indeed become a crucial issue for James Sloan, one of both political and personal significance. By 1801, Sloan had become an itinerant preacher

\footnotetext{
25 "At a Meeting of the Republican Committee Held at the House of Isaac Smallwood on the 6 "th of September 1800 " (Trenton: n. p., 1800), 2.

${ }^{26}$ Ibid., 6.

27 "An Address, Delivered at a Meeting of the Democratic Association of the County of Gloucester" (Trenton: Mann and Wilson, 1801), 3, 6-8.

28 Ibid., 10-11.

${ }^{29}$ Ibid., 15-16.
} 


\section{Bendler}

as well as a politician. An anonymous Federalist writer had excoriated Sloan's efforts to appeal to both the Quakers in Gloucester County and to the rapidly growing number of Methodists there. ${ }^{30} \mathrm{He}$ undercut Sloan's arguments by pointing out that both the Quakers and the Methodists had sent laudatory epistles to President Washington and had enjoyed unmolested liberty under the administrations of both Washington and his successor, John Adams. ${ }^{31}$

The Federalist writer also argued that "this man [Sloan] and his abettors are the miserable puppets of a dangerous and ambitious set of nabobs," the Virginia planter aristocracy. Appealing to antislavery sentiment common to Quakers and Methodists, the writer pointed out that Jefferson, portrayed as a "mild and amiable democrat" by Sloan, supported a system in which three to four hundred thousand "miserable negro slaves" remained in bondage in Virginia. He further noted that Jefferson "suggests the idea of their being a race inferior to the whites" even though true Christians believed African Americans were "of the same flesh and blood" as the rest of humanity. ${ }^{32}$

"Christianus," as the Federalist writer styled himself, also took exception to Sloan's sanguine characterization of the French Revolution. Rejecting Sloan's description of it as the "most magnanimous on earth," Christianus argued that the revolution in France had "drenched the world in blood and tears" and had "prostrated the only solid foundations of public prosperity and private felicity" in France itself. Revolutionary governments had abolished the Christian Sabbath and had substituted the "adoration of a harlot" for "worship of the only, ever-living and true God." 33 The writer urged his readers to adhere to "ancient principles" rather than turning to the radical ideas of people such as Thomas Jefferson and James Sloan. ${ }^{34}$

In 1801, Sloan faced disownment by the Quaker Haddonfield Monthly Meeting on account of his itinerant ministry. On June 8, 1801, the Preparative Meeting in Newton Township reported to the Haddonfield meeting that it had dealt with Sloan for "holding separate meetings for worship, from Friends, which he appeared to justify." 35 On August 10, the Haddonfield Monthly Meeting recorded a "minute of disownment" for holding "meetings under a profession of worship" in which Sloan undertook "to appear as a minister, which conduct being a manifest deviation and departure from our discipline." 36 Indeed, Sloan's personal religious beliefs were in the midst of a transformation. In this apparently short-lived itinerant ministry, Sloan sought to fuse Quaker and Methodist tenets, believing that Methodists preached for too long and Quakers did not do so enough. Evidently, very few people saw any wisdom in Sloan's idea, which he had dubbed the "United Brethren." ${ }^{37}$ Sloan then decided to devote himself to politics rather than preaching, and he did not follow up on his plans for a new religious organization.

Sloan pressed on with his political efforts, seeking to break the Federalist grip on Gloucester County. In 1801, he won the Democratic Republican nomination for the county's one seat in the

\footnotetext{
${ }^{30}$ For a discussion of the growth of Methodism in southern New Jersey, see Koedel, God's Vine, 138-165.

31 "Address to the Professors and Friends of the Christian Religion and Most Especially to the Religious Societies of People Called Friends and Methodists," (Trenton: Sherman, Mershon, and Thomas, 1801), 10-11.

${ }^{32}$ Ibid., 16.

${ }^{33}$ A reference to events during the French Revolution in 1793.

34 "Address to the Professors and Friends of the Christian Religion," 14.

${ }^{35}$ Minutes of the Haddonfield Monthly Meeting, 1781-1804, 417, FHL.

${ }^{36}$ Ibid, 420.

${ }^{37}$ Trenton Federalist, August 15, 1803.
} 
Council, then the upper chamber of the New Jersey legislature. In so doing, he entered into a rivalry with fellow Democratic Republican Joseph Cooper which, for at least four years, endangered the unity of the party's county organization. The state's leading Democratic Republican newspaper, the Trenton True American, reported that the county party organization nominated Sloan "notwithstanding the earnest and unremitted exertions of Joseph Cooper, Esq., in behalf of liberty and fellow citizens." The committee, without explaining its actions, thought it "expedient" to give its endorsement to Sloan. ${ }^{38}$ The Sloan-Cooper rivalry may have cost the Democratic Republicans the election in 1801. The final vote count showed that Federalist Thomas Clark won the Council seat with 1,092 votes, and Sloan finished second with 839 votes. But Joseph Cooper won 248 votes, and the two Democratic Republican rivals had a total number of votes only five less than the total cast for the Federalist Clark. In spite of this local setback, Democratic Republicans won control of the New Jersey legislature for the first time in $1801 .{ }^{39}$

Even while unsuccessfully seeking office in Gloucester County, Sloan established contacts with one of the state's leading Democratic Republican politicians, Silas Dickerson. Dickerson's brother Mahlon lived in Philadelphia and was active in city politics there. On October 27, 1801, Silas wrote his brother about a conversation with Sloan, in which Sloan alluded to an intimate acquaintance with Mahlon Dickerson. ${ }^{40}$ The next day, Silas reported that the Democratic Association of Gloucester County had "deputed" Sloan to "communicate a number of things of importance" to the legislature, then in session in Trenton, thus bypassing the county's mostly Federalist legislative delegation. Silas called Sloan "a man of natural as well as acquired talents," whom he found "agreeable in conversation."

The election of 1802 may have buttressed Silas Dickerson's impression of Sloan's political sagacity. Some Democratic Republican politicians, including Sloan, saw ominous portents for their party that year, just after it had gained control of the legislature in 1801. On March 29, 1802, Mahlon Dickerson wrote his brother about a conversation with Sloan in which Sloan reported that "all the influential characters in the lower part of the state" foresaw losses for their party in the legislative elections to be held in October. If the Federalists recaptured control of the legislature, they could reestablish district elections for members of Congress, putting the reelection of at least some of New Jersey's six Democratic Republican congressmen in jeopardy. Mahlon Dickerson concurred with Sloan's judgment, arguing that it would be "a great pity to run any [risk]." 42 The legislative leaders never called the special session, but, by late June, Dickerson found Sloan in "good spirits as to the result of your next election." 43

\section{Sloan Goes to Washington}

But Sloan's earlier fears proved justified, and, in October of 1802, the Federalists won a one-seat majority in the Assembly, even though the Democratic Republicans held on to an identical majority in the Council. Sloan himself lost another bid for election to that body. The deadlock delayed efforts to elect a governor, and also stymied efforts to enact a bill to set a date for the

\footnotetext{
38 True American, October 4, 1801.

${ }^{39}$ Election Returns, Folder 1801A, GCHS.

${ }^{40}$ Silas Dickerson to Mahlon Dickerson, October 27, 1801, Dickerson family papers, Box 3, NJHS.

${ }^{41}$ Silas Dickerson to Mahlon Dickerson, October 28, 1801, ibid.

${ }^{42}$ Mahlon Dickerson to Silas Dickerson, March 29, 1802, ibid.

${ }^{43}$ Mahlon Dickerson to Silas Dickerson, June 22, 1802, ibid.
} 
election of United States representatives. It was not until after the elections of October 1803, when the Democratic Republicans regained clear control in Trenton, that the General Assembly finally enacted a bill to set that date. The Federalists did not even nominate a slate of candidates, and James Sloan was one of six Democratic Republicans elected to Congress on a statewide ticket against only scattered opposition. He won election as a loyal Jeffersonian, and that loyalty manifested itself in his voting record and in his political rhetoric for most of his three terms in Washington.

Sloan did not go to Congress without opposition from within his own party. Silas Dickerson, once favorably impressed with Sloan, now voiced serious doubts about his temperament and qualifications, calling him "too violent for any office." 44 After travelling to Washington with Sloan and Ebenezer Elmer of Cumberland County, he again wrote his brother, expressing his concern about Sloan's "arbitrary" mindset, comparing him to Oliver Cromwell. He hinted that Sloan won election only by reaping "the interest of money he says he has spent in the republican cause for a number of years past." $" 45$

If anything, Sloan's politics were more radical, by contemporary standards, than those of Thomas Jefferson. According to some accounts, Sloan had made sharply satirical remarks about the United States Constitution, calling it the work of "traitors to their country, bribed by British gold." Sloan had in fact criticized certain provisions of the Constitution, such as the six year term for United States Senators, "one year short of the House of Commons in England." Also, the method of Presidential election allowed the minority "to impose a President on the majority," according to Sloan. He saw both provisions as "relics of the corrupt governments from which we emerged." 46

In 1804, Sloan again overcame the misgivings of some of his fellow partisans to win nomination for a second term in Congress. On June 19, 1804, two of his colleagues in the Eighth Congress expressed such misgivings. Writing to his colleague Ebenezer Elmer, Henry Southard characterized Sloan as selfish and overly ambitious. "I think with you that self is the cardinal point with Mr. Sloan and that the public good is not the object of his concern," he opined. According to Southard, Sloan had spoken harshly of his fellow representatives; thus, "neither the honor nor interest of the state can be promoted by being led by him." Southard implored Elmer to seek another term in Congress, reminding his Cumberland County colleague that he would have "ample support" in the northern part of the state. At the same time, Henry Southard hoped that Sloan's political machinations would prove self-destructive. ${ }^{47}$

James Sloan did win nomination to a second term in Congress. According to Silas Dickerson, he did so only by "bartering this way and that," winning despite having the support of only two county delegations when the convention convened in Trenton. Joseph Cooper again opposed

\footnotetext{
${ }^{44}$ Silas Dickerson to Mahlon Dickerson, November 27, 1803, ibid.

${ }^{45}$ Silas Dickerson to Mahlon Dickerson, January 22, 1804, ibid.

${ }^{46}$ Trenton True American, May 19, 1801. Sloan's concerns about the Senate and the Presidency echoed the AntiFederalist rhetoric of Philadelphia convention delegates Elbridge Gerry and George Mason, and the persistence of that rhetoric long after ratification of the Constitution. See Saul Cornell, The Other Founders: Anti-Federalism and the Dissenting Tradition in America, 1788-1828 (Chapel Hill: University of North Carolina Press, 1999), 1031.

${ }^{47}$ Henry Southard to Ebenezer Elmer, June 19, 1804, Simon Gratz collection, Historical Society of Pennsylvania, Philadelphia.
} 
Sloan, claiming that a number of fellow party members favored him. Dickerson, although sympathetic to Cooper's aims, feared that his scheme would "break into the ticket and would perhaps be attended with disagreeable circumstances." Furthermore, Sloan had evidently secured the support of Governor Joseph Bloomfield; Dickerson noted that "the governor and Sloan are in unison which I regret." Disgusted with how the convention was "bartering away the rights of the people," Dickerson regretted that he had not left Trenton sooner. ${ }^{48}$ The Spectator, a Philadelphia newspaper, reported that the "poor Cooperites" were "sadly disappointed and chagrined," outvoted as they were by "Jemmy Sloan."

In this controversial context, Sloan continued his service in the United States House of Representatives. He focused his attention on growing tensions with Great Britain over British treatment of American sailors and vessels on the high seas. On March 7, 1806, Sloan delivered two speeches on the issue of impressment of American sailors and mariners by the Royal Navy and the appropriate American response to it. At this point, he resolutely supported Jefferson's policy of a suspension of trade with Great Britain. To Sloan, the British, by opposing Napoleonic France, were "not fighting the battles of liberty." Sloan added that "friends of peace" should heartily approve the administration's position. The condescending British attitude toward the United States had not changed since the War of Independence. The Jefferson administration's policies provided the only means of challenging Britain while avoiding war. ${ }^{50}$

Sloan saw the Non-Intercourse Act as the best way to keep the peace and defend American rights on the high seas, arguing that non-intercourse would prove more effective than an enormous navy. ${ }^{51}$ Sloan's Quaker background, or perhaps his sizable Quaker constituency, still informed his views on foreign policy. Although disowned by the Quakers, his reference to the "friends of peace" indicated his recognition of a constituency averse to war. His conception of simplicity, whether informed by Quaker or republican tenets, surfaced in rhetoric directed against "fantastical articles of fashion." He shared the Jefferson administration's goal of simultaneously maintaining the peace and forcing the British to desist from their impressment of American sailors.

Despite his faithful support of Jefferson, locals opposed a third Sloan term in Congress. A supporter who wrote under the pen name "Jersey Blue" hinted at this opposition in an open letter to prospective voters. Some felt that Sloan's personal ambition exceeded his devotion to the Democratic Republican cause. Jersey Blue refuted those notions. He called Sloan a "decided republican" who held the "esteem and confidence of the real democratic republican members [of Congress]." He had proven his allegiance by being "foremost" to oppose the renegade Virginian John Randolph of Roanoke. Removing Sloan from the ticket would manifest a "want of confidence" in President Jefferson himself. ${ }^{52}$

\footnotetext{
${ }^{48}$ Silas Dickerson to Mahlon Dickerson, October 24, 1804, Dickerson family papers, Box 3, NJHS.

${ }^{49}$ The Spectator, Philadelphia, November 3, 1804.

${ }^{50}$ Two Speeches Delivered in the House of Representatives, March 7 and March 17, 1806, by Mr. Sloan (n. p., 1806), 3-6.

${ }^{51}$ Ibid., 14.

${ }^{52}$ Centinel of Freedom, Newark, New Jersey, September 9, 1806. For Randolph's sentiments about Sloan, see Russell Kirk, John Randolph of Roanoke, A Study in American Politics (Indianapolis, Indiana: Liberty Press, 1978), 51-52, 91, 337.
} 
The Federalist United States Gazette of Philadelphia reported that a "great many men came to Trenton" to nominate the Democratic Republican ticket for Congress in 1806. The Gazette made particular note of Sloan's nomination for a third term in Congress. It reported that Ebenezer Elmer of Cumberland County, "one of the best qualified men," was left off the ticket, being "too moderate [a] man" for the Democratic Republicans of New Jersey. ${ }^{53}$ Clearly, Sloan's opposition to Randolph carried the day for him. Mahlon Dickerson affirmed that the "bold stand he [Sloan] made against Randolph" made the difference. Otherwise, "he would have undoubtedly been left off" the party's ticket. Even so, Dickerson vowed to oppose Sloan and two other nominees, Aaron Ogden and John Beatty. ${ }^{54}$ Silas Dickerson responded agreeably to his brother, noting that Elmer was "not quite Jacobinic enough for the times."

James Sloan won reelection in 1806, but the entire Democratic Republican congressional ticket faced more than scattered opposition for the first time since 1800. In addition to the Federalists, the ticket faced the opposition of Democratic Republicans unhappy with their own party's nominees, opposition that included Ebenezer Elmer. Four Federalists and three renegade Democratic Republicans opposed the six party-backed nominees. Nevertheless, those nominees easily turned back the challenge. James Sloan trailed all of his fellow organization-backed nominees, receiving 10,959 votes, nearly 2,700 fewer than William Helms, who led the ticket and won ninety-five percent of the votes cast. Ebenezer Elmer received 5,703 votes, and he may have drawn some of those from James Sloan. ${ }^{56}$

By the time Sloan won his third term in Congress, the constitutional ban on restricting the slave trade neared its expiration on January 1, 1808. This restriction, coupled with the mandate that the slave population be counted as three fifths of its total for congressional apportionment and direct taxation, kept the issue of slavery in the political arena. As Congress debated banning the slave trade in 1806 and 1807, advocates of further restrictions on slavery had opportunity to state their case. With the support of the Jefferson administration and representatives from the upper South, Congress did impose a ban on the slave trade. That debate gave opponents of slavery such as James Sloan the opportunity to seek tougher enforcement provisions. ${ }^{57}$

Sloan took advantage of that opportunity. On December 17, 1806, he offered an amendment to the bill ending the importation of slaves that would mandate the freeing of any slaves forfeited by smugglers. Fearful of the presence of free blacks in their states, southern Democratic Republican representatives vigorously opposed Sloan's amendment and it did not win approval. In place of Sloan's amendment, Congress mandated that the human cargo of such trading vessels would be delivered "to such person or persons as shall be appointed by the respective states to receive the same." 58

\footnotetext{
${ }^{53}$ United States Gazette, Philadelphia, Pennsylvania, September 24, 1806.

${ }^{54}$ Mahlon Dickerson to Silas Dickerson, October 6, 1806, Dickerson family papers, Box 3, NJHS.

55 Silias Dickerson to Mahlon Dickerson, October 12, 1806, ibid.

${ }^{56}$ Michael J. Dubin, ed., U. S. Congressional Elections, 1788-1997: The Official Results (Jefferson, North Carolina: McFarland and Company, 1998), 36.

${ }^{57}$ For a discussion of the role of slavery in national political discourse at this time, see Matthew Mason, Slavery and Politics in the Early American Republic (Chapel Hill: University of North Carolina Press, 2006), 40-41. Mason points out that issues connected with slavery became a matter of national concern long before the debate over the Missouri Compromise in 1819-20.

${ }^{58}$ For a summary of Congressional action on Sloan's amendment, see W. E. B. Du Bois, The Suppression of the African Slave-Trade to the United States of America, 1638-1870 (Millwood, New York: Kraus Thompson, Ltd.,
} 
Even so, Sloan continued to support his party. At a meeting held in the Gloucester County seat at Woodbury on August 31, 1807, he lauded his own "noble, patriotic party," while excoriating the Federalists as a "base faction" composed of lawyers who lived off the "folly, wickedness, and distress of the people," clergymen who desired a state religion, and pro-British merchants who wanted to control American diplomacy. The Federalists campaigned as "federal republicans," but Sloan saw deception even in this label. The party, he claimed, remained an "implacable enemy to democracy." Sloan again emphasized Jefferson's efforts to maintain peace while protecting American interests abroad. While John Adams, according to Sloan, had resorted to bellicose measures, Jefferson attempted to peacefully resolve the ongoing international crisis. ${ }^{59}$

Sloan's pamphlet drew a predictable reaction from the Federalist press. One Federalist writer called it a "rare pamphlet setting forth rare assertions on a rare occasion leading to rare conclusions." Sloan gave the Federalists a "most vigilant and old-woman scolding," abounding "trope upon trope from simple comparison up to learned hyperbole." Most of all, he questioned Sloan's conception of party and faction. Federalists, of course, would not see their party as a "base faction" and would be more prone to so view their opposition. At the end of 1807, Sloan's "decided" loyalty to the Jefferson administration appeared unwavering. But his politics would soon be transformed by events and by a new approach taken by the Jefferson administration to the international crisis. 60

\section{Sloan Breaks with His Party}

In 1808, James Sloan broke with his party's administration and with the majority of his Democratic Republican colleagues in Washington and in New Jersey. Three issues - the Embargo, removal of the nation's capital from Washington, and the selection of the Democratic Republican nominee for President in 1808-defined Sloan's emerging differences with his party. On each, Sloan found himself at odds with the prevailing sentiment in the party. His increasing independence led to his exclusion from the congressional ticket in 1808. Four years later, Sloan broke with the Democratic Republican party to support a revival of Federalism in New Jersey. ${ }^{61}$

Since the outbreak of war in the early 1790s between revolutionary France and the various coalitions allied against it, the United States had sought to preserve its rights as a neutral nation while avoiding actual combat. On December 22, 1807, President Jefferson signed the Embargo Act, ostensibly to protect American property and to pressure European powers to acknowledge American neutral rights. Despite concerns about its efficacy, particularly from Treasury Secretary Albert Gallatin, the administration prevailed on Congress to pass three supplementary acts in the winter and spring of 1808. Those acts, which stiffened penalties and tightened enforcement procedures, became law on January 8, March 12, and April 24, 1808, respectively. ${ }^{62}$

1973), 96-101 and 244-5. Also see Matthew E. Mason's discussion in “Slavery Overshadowed: Congress Debates Prohibiting the Atlantic Slave Trade to the United States" in The Journal of the Early Republic 20, no. 2 (Spring 2000), 64-68.

59 “[Proceedings] at a Meeting of the Democratic Republicans of Gloucester County," n. p., 1807.

${ }^{60}$ Trenton Federalist, September 18, 1807.

${ }^{61}$ Sloan's break was so definitive that historians have misidentified him as a Federalist. For example, see Richard Buel, America on the Brink (New York: Palgrave Macmillan, 2005), 66-67.

${ }^{62}$ For discussion of the enactment of these laws, see Burton Spivak, Jefferson's Economic Crisis: Commerce, Embargo, and the Republican Revolution (Charlottesville: University Press of Virginia, 1979). 
James Sloan voted for the first Embargo Act and its first two supplements. In response to a speech denouncing the Embargo by Philip Key, a Maryland Federalist, Sloan asserted that Key had "only convinced him of the propriety of the measure." Indeed, he compared the effectiveness of Key's argument to that of "a boy's pop gun against the mighty castle in which we now sit." 63 Sloan coupled his support for the Embargo with opposition to raising a standing army. Eight days earlier, Sloan had spoken against a bill for that purpose, arguing that "there was not half the reasons for raising an army now, as in 1798.",64

By the end of April 1808, however, Sloan expressed doubts about the Embargo. As debate on the third supplement to the Embargo Act came to an end, Sloan continued to "profess his attachment to the embargo" but he also stated that the "details of the bill would be very injurious to divers[e] good people among his constituents and in other parts of the United States." Even so, the House passed the bill by a vote of seventy three to twenty six. For the first time, Sloan opposed the policy so assiduously supported by the administration and the majority of his party. ${ }^{65}$ Sloan wrote his constituents and promised that he would not support "forging chains for you and your posterity." Using language he once had directed against the Federalists, he pledged to no longer "enjoy the smiles of courtly sycophants and servile dependents upon executive patronage and the public treasury." 66

Sloan's change of heart on the Embargo reflected a growing disillusionment with his party and its leadership. His disenchantment with how the Democratic Republicans exercised power again revealed itself when he offered a motion in Congress to move the capital of the United States from Washington back to Philadelphia. Establishment of the "federal city" on the banks of the Potomac was the product of a political deal to gain southern support for Alexander Hamilton's financial programs. Sloan's motion, had it won approval, would have directly assaulted what many of his fellow Democratic Republicans regarded as sacrosanct. Sloan also stated his belief that the District of Columbia's existence was inconsistent with the natural rights and liberties that guaranteed all Americans, "a system admitting of monarchical despotism," arguing that the District's appointed government violated the principle of self-government. ${ }^{67}$

Sloan's proposal to move the capital was, of course, defeated, though not without gaining considerable support. On February 5, 1808, the House of Representatives took up Sloan's resolution on the subject. Although Sloan withdrew it, Representative Thomas Blount of North Carolina "renewed" the resolution. The motion won fifty-one affirmative votes against sixtyeight in opposition. ${ }^{68}$ Sloan's suggestion also won some support in the press. A writer for Poulson's Daily Advertiser argued that Philadelphia had "gained in extent and beauty," as well as "culturally and economically." Even if one factored in mortality rates during the yellow fever epidemics of the 1790s, Philadelphia was still a healthier city than Washington. The capital on

\footnotetext{
${ }^{63}$ Debates of Congress of April 13, reported in The Commercial Advertiser, New York, April 18, 1808.

${ }^{64}$ Debates of Congress of April 5, reported in The Newburyport Herald, Newburyport, Massachusetts, April 19, 1808.

${ }^{65}$ Journal of the House of Representatives of the United States, at the First Session of the Tenth Congress (Washington: A. and G. Way, 1808), 299-300.

${ }^{66}$ Sloan to his constituents, letter published in the Middlesex Gazette, Middletown, Connecticut, May $12,1808$.

${ }^{67}$ James Sloan, Revisions Offered to the Consideration of the Citizens of the United States in Favor of the Removal of the Seat of Government from Washington City (Washington, 1808), 3-4.

${ }^{68}$ Journal of the House of Representatives, Tenth Congress, First Session, 182-183.
} 
the Potomac had so languished that "even the wind of speculation ceases to blow it into consequence." 69

Finally, Sloan broke with his party over its choice of James Madison to succeed Jefferson to the presidency in the election of 1808. On January 23, 1808, Democratic Republican members of Congress convened in the Senate chamber and recommended the election of Madison as the next President. By his own account, Sloan had at that time voted with the caucus, mainly to "unite the republican interest." Later on, he claimed to have discovered "a combination of causes and effects connected with his [Madison's] election" that he considered "dangerous to the liberty and interest of the United States."

Sloan did not offer specific reasons why Madison's election endangered the "liberty and interest" of the country, but he did hint at some of his misgivings. First, he wondered why the party held its caucus so early in the legislative session. Was there a "latent design" or "improper motives"? He stated his preference for a ticket of Vice-President George Clinton for President and James Monroe for Vice-President. He then restated his arguments for moving the nation's capital, following that with a statement of opposition to unspecified appropriations for the "express purpose of forging chains for you and your posterity." He evidently saw a connection between the location of the capital and Virginia's influence in national politics, again rejecting the "smiles of courtly sycophants and servile dependents on executive patronage" in Washington. ${ }^{70}$

In the midst of the controversies over moving the nation's capital and the election of 1808, the Embargo remained very much on Sloan's mind. In a speech to the House of Representatives on November 19, 1808, Sloan questioned the constitutionality of the Embargo. Congress, Sloan argued, had the constitutional power to regulate commerce, not to "annihilate" it. ${ }^{71}$ He further argued that continuance of the Embargo played into the hands of its intended victims: Great Britain and France. Additionally, it deprived the United States of profitable trade contacts. If the Embargo were lifted, Americans could trade with Spain and Portugal, where Napoleon's armies were locked in an increasingly brutal war. Perhaps American trade could even deliver Iberia from the "rapacious fangs of the insatiable conqueror," Napoleon Bonaparte. Simultaneously, the Embargo had caused increasing hardships among Sloan's own New Jersey constituents, as well as among their commercial contacts in Philadelphia. ${ }^{72}$ In a second speech on December 27, 1808, Sloan described the Embargo as an instrument of oppression, enforceable only by "tyrannical" methods. Its repeal would preserve, not endanger, peace. ${ }^{73}$

\footnotetext{
${ }^{69}$ Poulson's Daily Advertiser, Philadelphia, March 23, 1808.

70 "Extract of an Address to the Citizens of New Jersey by the Honorable James Sloan," printed in the Alexandria Advertiser, Alexandria, Virginia, April 28, 1808. For a summary of the nomination process, see Noble Cunningham, The Jeffersonian Republicans in Power: Party Operations, 1801-1809 (Chapel Hill: University of North Carolina Press, 1963), 108-124. Sloan emerged at the cutting edge of northern and eastern (New England) opposition to the "Virginia Dynasty." For an account of this opposition, see J. C. A. Stagg, "James Madison and the Malcontents: The Political Origins of the War of 1812," in William and Mary Quarterly, 3 rd Series (October 1976), 557-585. Saul Cornell notes that Clinton supporters turned to "older anti-Federalist language to frame their opposition to the party leadership." See Cornell, The Other Founders: Anti-Federalism and the Dissenting Tradition in America, 1788-1828 (Chapel Hill: University of North Carolina Press, 1999), 276 and 301.

${ }^{71}$ The Speeches of James Sloan Delivered During the Session of 1808-9 Together with his Letter to the Citizens of Philadelphia (Philadelphia: Thomas T. Stiles, 1809), 3-7.

${ }^{72}$ Ibid., 5.

${ }^{73}$ Ibid., 10-17.
} 


\section{Bendler}

Ever more forcefully, Sloan expressed his growing disillusionment with the Virginia leadership of his party. In so doing, he vigorously restated his opposition to slavery. He pointed to the dissonance between the rhetoric of liberty and individual rights proclaimed by the party and its espousal of slavery in the Old Dominion and elsewhere, pointing out that, in Virginia alone, 346,968 "human souls are kept in a perpetual state of bondage." He also noted that only about twenty five thousand voters elected Virginia's twenty two members of Congress. In his home state of New Jersey, over thirty two thousand voters elected that state's six congressmen in 1808. Indeed, he portrayed Virginia as the antithesis of a truly democratic government. The principles of the Declaration of Independence had become a "sounding brass or a tinkling cymbal" in the Old Dominion. $^{74}$

In a letter accompanying his published speeches, Sloan saw the Embargo as a tool of "Southern Nabobs" who, "flushed with the election of another Virginia President," wanted to "silence all opposition." 75 Such rhetoric revealed much larger differences between the now lame-duck congressman and the Virginia leadership of his party. Sloan saw support for slavery and low political participation in Virginia as evidence that his political party did not truly practice the democracy it espoused. He saw a growing divergence between the concerns of the Virginians and his own constituency of small farmers, many of whom were Quakers. Additionally, he saw the impact of the Embargo on the commerce of Philadelphia, just across the river from his home in Newton Township. His involvement in ferrying people and produce across the river had undoubtedly left him very cognizant of the plight of his own constituents and their contacts across the Delaware River. ${ }^{76}$

Sloan did not win re-nomination to Congress in 1808; the party replaced him with Jacob Hufty of Salem County. In a pamphlet published soon after leaving office, by which time Congress had repealed the Embargo, Sloan again dwelt on the two issues of importance to him: the Embargo and removal of the nation's capital from Washington to Philadelphia. He saw the Embargo as the "greatest evil these United States have experienced since the Revolutionary War." To Sloan, that issue and removal of the capital were "twin sisters." Both, in his mind, "were equally destructive of the lasting interest, peace, and prosperity of these United States." To James Sloan, power had corrupted the party that he had once worked for with indefatigable zeal. ${ }^{77}$

In 1809, Sloan's political career appeared to be at an end. On March 3, 1809, a Democratic Republican meeting in Salem County commended his "former services" in the "republican cause" but noted "decided disapprobation of his late conduct" in Congress. Sloan's "untimely opposition" to the Embargo promoted discord "when unanimity was never at any period more

\footnotetext{
${ }^{74}$ Ibid., 12. Matthew Mason points to Federalist preoccupation with the three fifths clause in the Constitution because it inflated Democratic Republican political strength. Sloan's concern with the matter also reflects opposition to slavery itself as well as emerging sectional tension within the Democratic Republican party. See Mason, "Nothing is Better Calculated to Excite Divisions': Federalist Agitation against Slave Representation during the War of 1812," in New England Quarterly 75 (December 2002), 531-561.

75 Ibid., 19.

${ }^{76}$ Louis Martin Sears argued that although the Embargo brought "real and somewhat widespread distress" to Philadelphia, it sparked the development of industry and proved beneficial. Sloan's contacts in the city, however, would have most likely felt the "widespread distress." See Sears, "Philadelphia and the Embargo of 1808," in The Quarterly Journal of Economics 35 (February 1921), 354-359.

77 Politics for Farmers (Philadelphia: Freeman's Friend Office, 1809), 1-5.
} 
necessary to the public interest and safety." ${ }^{, 78}$ In 1811, James Sloan's apparent political death was accompanied by false reports of his physical death. In November 1811, newspapers across the country reported Sloan's death at his home in Newton Township. ${ }^{79}$ Sloan, indeed, had been seriously ill for about two weeks, but he did recover. Although he never again held elective office, he returned to the political arena in 1812 and opposed the party that he had long supported, working for and with former opponents.

\section{A Friend of Peace}

Sloan spoke out against the increasingly bellicose stance of the Madison administration and the "war hawks" in Congress. As sentiment for war with Britain increased, he took a strong stand against its declaration. ${ }^{80}$ Early in 1812 , he wrote a pamphlet challenging the wisdom of going to war. He saw no positive gains from the conflict should it occur. The conquest of Canada, one of the stated aims of the "war hawks," would prove costly. Occupying Canada would require a large, expensive army, the kind of military establishment that Sloan consistently feared. Furthermore, the United States would not obtain assistance from Revolutionary-era allies such as France, Spain, and the Netherlands. The Royal Navy would thus be able to plunder the eastern seaboard at will. ${ }^{81}$

War with Great Britain provided the ultimate justification for Sloan's break with the Democratic Republican party. Sloan pointed out that administration policies particularly hurt the midAtlantic and New England states, recalling the similar effects of the Embargo in 1808. He argued that those states had supported the Virginia dynasty "contrary to the interests of their constituents." Sloan proposed election of an "eastern" President in 1812 and again suggested moving the capital to Philadelphia. Only if removed from a location "surrounded by slaves and slaveholders" and a "set of war hawks and other idle drones" would open government flourish. He went on to excoriate the three-fifths clause in the Constitution which gave the slave states a disproportionate role in the House of Representatives and in the Electoral College. That, combined with "the weight of executive influence" and the "virulence of party politics," Sloan contended, kept the Virginians in power. ${ }^{82}$

Election of New York Governor Dewitt Clinton would redress these injustices. To Sloan, Clinton was the most qualified to "preside over a great, industrious, and free people." Madison, the Virginian, would by his education and local bias, favor "that anti-Christian, tyrannical, and inhuman principle of slavery of the human species." Clinton's election would lead to "peace with honorable terms" and would "reintroduce genuine republican principles." For too long, Sloan argued that the rights of middle and eastern states had been sacrificed to party "political rage" with "pretended republicans" controlling the government. ${ }^{83}$

\footnotetext{
${ }^{78}$ True American, September 5, 1808.

${ }^{79}$ One such account was in the Trenton Federalist, November 11, 1811.

${ }^{80}$ For an account of anti-war sentiment in New Jersey and its impact on the state's politics, see Harvey Strum, "New Jersey Politics and the War of 1812," in New Jersey History 105 (Fall/Winter 1987), 37-69.

${ }^{81}$ An Address to the Citizens of the United States, Particularly those of the Middle and Eastern States (Philadelphia: Thomas T. Stiles, 1812), 3-5.

${ }^{82}$ Ibid., 10-12.

${ }^{83}$ Ibid., 11-14. Steven Edwin Siry notes that Democratic Republican insurgents favored a greater role for commerce and a less privileged role for southern agrarians. Sloan took the insurgency a step further by emphasizing and attacking the role of slavery in the southern domination of the Democratic Republican party. See Siry, "The
} 
Sloan coupled his antiwar position with his longstanding opposition to slavery, insinuating that the Virginia slaveholders had led the rush to war and were ill-qualified to lead a party professing faith in liberty and individual rights. Federalists and renegade Democratic Republicans such as Sloan found common ground in 1812. Three Democratic Republican congressmen from New Jersey and one of its senators - John Lambert - also opposed the declaration of war, and the Federalists supported those three members of Congress, one of whom was Jacob Hufty, the party loyalist who had replaced Sloan on the Democratic Republican ticket in 1808. The Federalists also endorsed Dewitt Clinton for President, linking the national and local campaigns in New Jersey. A new political coalition, the "Friends of Peace," received Sloan's endorsement along with the support of other antiwar Democratic Republicans.

Sloan's polemics on behalf of the "Friends of Peace" won him the scorn of some of his erstwhile colleagues and the praise of some former opponents. A Philadelphia periodical, The Tickler, ascribed Sloan's change of heart to ambition. A writer for the paper reviewed Sloan's Address to the Middle Atlantic and Northeastern States and also attributed it to political ambition. Not having been named ambassador to the "Court of St. Cloud," Sloan deserted his colleagues who would "not reward his faithfulness." " The Tickler sneeringly labeled Sloan "the standing joke of the Jerseys" and claimed that the apostasy of a "little chattering Jersey hog merchant" would neither hurt the Democratic Republican party nor help the Federalists. ${ }^{85}$

In addition to his polemics, Sloan helped to organize the opposition to Madison's reelection. On June 6, 1812, he attended a meeting chaired by Federalist Franklin Davenport. Sloan had once worked with Davenport in the antislavery movement, but Davenport had become a Federalist leader in Gloucester County when Sloan led the opposition. In 1812, opposition to war brought them together once again. Davenport appointed Sloan to a five-member committee to draft resolutions "expressive of the sentiments of the meeting on the present truly distressing situation of our common country." Among the five resolutions offered by the committee's report and adopted by the meeting was one calling the "war measures" under consideration by Congress "highly injurious to the best interests of the people of these states.",86

Sloan thus regained respect and influence in Gloucester County. A meeting of the "Friends of Peace" in Woodbury on August 1, 1812, stated its opposition to the war, calling on Congress to rescind the declaration of war on Great Britain. In so doing, the "Friends of Peace" made note of antiwar sentiment across southern New Jersey, and they cited the "impressive observations" by Sloan and others as favorable harbingers for the state elections still months in the future. Sloan and his new political allies saw the election of Dewitt Clinton, who had expressed "his decided disapprobation of the ruinous measures pursued by the administration," as the only hope for ending such "ruinous" policies. ${ }^{87}$

Sectional Politics of Practical Republicanism: DeWitt Clinton's Presidential Bid, 1810-1812," in Journal of the Early Republic 5 (Winter 1985), 441-462.

84 "St. Cloud" may be a sarcastic reference to the Court of St. James in Great Britain.

${ }^{85}$ The Tickler, Philadelphia, October 6, 1812.

${ }^{86}$ Trenton Federalist, June 5, 1812.

${ }^{87}$ Trenton Federalist, August 24, 1812. 
The "Friends of Peace" ticket won an impressive victory in Gloucester County and across New Jersey. Since 1808, elections in that county had been closely contested. In 1811, for example, only thirteen votes, of nearly 2,800 cast, separated the victorious Democratic Republican candidate for Council, Isaac Mickle, from his Federalist challenger. Voters in the county also elected two Federalists and one Democratic Republican to the Assembly. ${ }^{88}$ In 1812, turnout increased to over 3,300, and the Federalists won the Council seat and all three Assembly seats by nearly 400 votes. ${ }^{89}$ The Gloucester County returns reflected a statewide trend. The Federalists captured control of the New Jersey legislature, and Dewitt Clinton won the state's eight electoral votes.

Even as Madison defeated Clinton nationwide and won a second term as President, Sloan worked to elect the "Friends of Peace" to Congress in New Jersey's newly-created Third Congressional District. ${ }^{90} \mathrm{He}$ served as a delegate from Gloucester County to a meeting held in Salem on December 16, 1812. That meeting nominated William Coxe of Burlington County and Jacob Hufty of Salem County as candidates for the district's two seats in Congress. Coxe had unsuccessfully run on the Federalist ticket against Hufty in 1808. On January 12 and 13, 1813, voters in the district elected those two candidates with only scattering opposition. ${ }^{91}$

Sloan's political renaissance proved short-lived. When the Federalists recaptured control of the New Jersey legislature in 1812, Sloan did receive an appointment to an office of profit, being named president of the newly chartered Bank of Camden in 1813. Nevertheless, personal financial setbacks apparently forced Sloan to end his public service and eventually compelled him to leave New Jersey. Faced with financial losses and the loss of his own property, he decided to relocate to upstate New York, where he had purchased property. On November 13, 1813 , as a result of a court order to pay off Sloan's indebtedness, the sheriff of Gloucester County sold his land to Thomas Astley of Philadelphia for $\$ 18,000 .^{92}$

Before leaving Gloucester County, Sloan once again sought to justify his break with the Democratic Republican party. In 1813, he published "The Hypocrite Unmasked," responding to a pamphlet attacking him during the campaign of 1812. He compared its anonymous author to the beast mentioned in the biblical Apocalypse, refuting its arguments with equal vehemence. He again charged the Democratic Republicans with placing "party political rage" ahead of the interests of the "Eastern and Middle states," which had nothing to gain from the war with Great Britain. "Representatives of slaves and slaveholders" had perpetuated the war, "whose antirepublican and tyrannical conduct" well fitted them to abet the cause of "that ambitious tyrant" Napoleon Bonaparte. Advocates of war had also ignored efforts by the British government to return impressed American sailors who were documented American citizens. Sloan urged his readers to "use the lawful and peaceable measures provided in our constitution to arrest the ruinous measures of the present." 93

\footnotetext{
${ }^{88}$ Election Returns, Folder 1811A, GCHS.

${ }^{89}$ Ibid., Folder $1812 \mathrm{C}$.

90 That district included Burlington, Gloucester, Salem, Cumberland, and Cape May counties. The Federalist legislature elected in 1812 had divided the state into three congressional districts, each electing two members to the House of Representatives.

${ }^{91}$ U. S. Congressional Elections, 1788-1987, 50.

${ }^{92}$ Gloucester County Deeds, W:372.

93 James Sloan, "The Hypocrite Unmasked, Remarks on an Address to the Freemen of Gloucester," October 11, 1813, Broadside at the Salem County Historical Society, Salem, New Jersey. Sloan published this broadside in the
} 
After this final effort at self-vindication, James Sloan spent the remainder of his life in Tioga County, New York. On March 30, 1815, he leased a grist mill and a saw mill from Timothy Owen of Elmira. ${ }^{94}$ From time to time, he participated in the political life of his new home state. On July 4, 1819, he delivered an oration in Newtown in Tioga County, expressing disgust at the "alarming progress of a now numerous horde of internal enemies," "a great and powerful moneyed aristocracy." He urged his listeners to reject "foreign luxuries" and promote "morality and pure, unspoiled virtue." 95 Six years later, Sloan wrote to Governor Dewitt Clinton. He urged the governor to support construction of a canal linking the upper Susquehanna watershed with the new Erie Canal to provide a means of transporting coal and iron ore found in Tioga County to outside markets. Sloan also sent personal regards to Clinton and commented on his own health, noting that he had recently suffered an illness "nigh unto death," but had recovered and was "now stronger and more active than before I was sick." 96

On November 18, 1829, James Sloan wrote a plaintive letter to James Madison, whose candidacy for the Presidency he had twice opposed. Sloan wrote primarily to promote a pamphlet he had written entitled "Priestcraft Unmasked," a scathing critique of the ordained clergy and of orthodox Christian doctrines such as predestination, the Trinity, and original sin. He urged Madison, if interested in a copy, to respond to him through Thomas Marshall, then a congressman from upstate New York. But he also sought to make amends for the political differences of years past. He asked Madison to "remember me affectionately" to James Monroe and John Randolph of Roanoke, praising their "friendship to equal liberty and the inherent rights of man" and "opposition to aristocracy when making rapid strides to overturn the government of these United States." He went on to express his esteem for Madison himself and "my dear deceased friend Thomas Jefferson." Sloan characterized this missive as a "final farewell" from one "on the brink of the grave, the edge of eternity." Near the end of his own life, Sloan evidently remembered the reasons for his initial collaboration with the Virginians rather than those issues that led him to repudiate their leadership. ${ }^{97}$

James Sloan died on September 7, 1831, in Southport, New York. Sloan's beliefs, political and otherwise, defy easy categorization. He served as a militiaman in the Revolutionary War, even though his Quaker faith forbade military activity. Like most Quakers, he opposed slavery. In politics, he became a staunch Jeffersonian at a time when most Quakers in south Jersey supported Federalists. He built a Democratic Republican organization that ended the Federalist domination of Gloucester County, and he won election to three terms in the United States House of Representatives. But his growing disenchantment with his party led him to break with it, thus ending his political career. Nonetheless, his "irascible" personality and his opposition to what he saw as inconsistency left a mark on New Jersey and national politics. Both state and national

context of efforts by the Madison administration to impose another embargo, efforts which failed in July of 1813 but won congressional approval in December of that year. See J. C. Stagg, Mr. Madison's War: Politics, War and Diplomacy in the Early American Republic, 1783-1830 (Princeton, Princeton University Press, 1983), 318-9 and 363-5.

${ }^{94}$ Lease from Timothy Owen to James Sloan, March 30, 1815, Sloan family papers, Chemung County Historical Society, Elmira, New York.

${ }^{95}$ Daily Advertiser, New York, New York, July 30, 1819.

96 James Sloan to Dewitt Clinton, September 2, 1825, Sloan family papers, Chemung County Historical Society.

97 James Sloan to James Madison, November 18, 1829, James Madison Papers, Library of Congress, accessed at http://llhdl.loc.gov/loc.mss/mjm.22_1156_1158, February 2, 2007. 
party leaders viewed Sloan as an undependable, inconsistent renegade. Sloan would have claimed for himself the virtue of consistency when others cast it aside, corrupted by their pursuit of power and influence. He no doubt perceived himself as one of only a few true, consistent Democratic Republicans. Some of his peers came to agree. 